Original scientific paper - Izvorni znanstveni rad

UDK: 637.146 .21

\title{
Microbiological, physicochemical, and sensory characteristics of kefir produced by secondary fermentation
}

doi: $10.15567 /$ mljekarstvo.2018.0305

\author{
Filiz Yıldız-Akgül ${ }^{*}$, Atila Yetişemiyen ${ }^{2}$,Ebru Şenel ${ }^{2}$, Zeliha Yıldırım $^{3}$ \\ ${ }^{1}$ Adnan Menderes University, Agriculture Faculty, Department of Dairy Technology, \\ Aydin 09100, Turkey \\ ${ }^{2}$ Ankara University, Agriculture Faculty, Department of Dairy Technology, \\ Ankara 06110, Turkey \\ ${ }^{3}$ Ömer Halisdemir University, Engineering Faculty, Department of Food Engineering, \\ Niğde 51240, Turkey \\ Received - Prispjelo: 18.04.2017. \\ Accepted - Prihvaćeno: 18.04.2018.
}

\begin{abstract}
In this study, the microbiological, physicochemical, and sensory properties and volatile aromatic compounds of kefir produced by secondary fermentation were investigated. Cow milk samples containing $1.5 \%$ fat were fermented with kefir grains until the $\mathrm{pH}$ reached certain levels $\mathrm{pH}$ 5.05.5), and then each of them was inoculated with a different starter culture (thermophilic, probiotic, mesophilic aromatic, and yeast) for secondary fermentation. In kefir samples produced traditionally or by secondary fermentation, the $\mathrm{pH}$ values, carbon dioxide levels, and tyrosine and lactic acid contents increased during storage. However, the counts of lactococcus, lactobacillus, leuconostoc, and yeasts decreased. Acetaldehyde and ethanol increased during storage, but diacetyl decreased in kefir samples produced traditionally or by secondary fermentation. The butanone contents changed very little but they showed an upward trend within the storage period. Kefir samples produced by secondary fermentation found greater acceptance during sensory testing than samples produced by the traditional method. Kefir inoculated with mesophilic aromatic and yeast cultures were the most preferred by panelists.
\end{abstract}

Key words: kefir, secondary fermentation, microbiology, physicochemical properties, volatile aroma compounds, sensory quality

\section{Introduction}

The nutritional value and therapeutic properties of fermented milk products such as kefir, yogurt and kumis have aroused considerable interest in such "novel" milk foods. The name kefir has been proposed to originate from the Turkish word "Keyif," which means "good feeling," and its consumption is associated with an overall sense of health and wellbeing (Chaitow and Trenev, 2002). Kefir differs from other fermented milk products due to a different starter culture that exists in the form of "grains" and has a unique taste and properties. The grains have a particular structure and behave as biologically vital organisms. They grow, propagate, and pass their properties on to the succeeding generation of new grains. The microflora of kefir grains is remarkably stable, retaining their activity for years when preserved and incubated under appropriate culture and physiological conditions. Kefir grains have a complex microbiological composition that has been proven to contain lactobacilli, lactic streptococci, leuconostocs, yeasts and acetic acid bacteria. Therefore, kefir is characterized by lactic acid and yeast fermentation (Magra et al., 2012; Vieira et al., 2015; Kesenkaş et al., 2017). 
Traditional kefir is prepared by adding kefir grains to milk and incubating with stirring at $24-26^{\circ} \mathrm{C}$ until the $\mathrm{pH}$ drops to 4.6. After incubation, the kefir grains are removed by sieving (Güzel-Seydim et al., 2000a, b; Otles and Cagindi, 2003). The industrial manufacture of kefir using grains as a starter culture is very difficult because of their complex microbiological composition, which widely varies depending on the origin of the grains and conditions of storage and handling. Wide variation in the microflora of kefir grains makes it difficult to obtain an optimal and uniform starter culture necessary for obtaining a quality kefir (Beshkova et al., 2002; GarciaFontain et al., 2006; Güzel-Seydim et al., 2005; Sarkar, 2007, 2008; Montanuci et al., 2012).

The taste and aroma in kefir are not standardised (Glibowski and Zielinska, 2015). The ratios of lactic acid, ethyl alcohol, and flavour components of kefir can be different in each dairy plant (Puhan, 1988). The uniform flavour of traditional kefir is a result of the symbiotic activity of many types of bacteria and yeast contained within the kefir grains. Use of starter cultures in kefir production allows the formation of a standardized product that can be controlled (Beshkova et al., 2003; Pawlos et al., 2016). For that reason, a two-stage fermentation technique developed to control the taste and flavour development of kefir has been gaining importance in recent years.

Traditionally and industrially, kefir has been obtained by fermenting milk with kefir grains, or a bulk starter obtained by culturing milk with kefir grains in single-stage fermentation. However, it has been reported that the secondary fermentation technique encourages microorganism activity and accelerates metabolic changes in milk (Özer et al., 2000). Therefore, the present study was conducted to assess the microbiological, physicochemical, and sensory attributes of kefir products manufactured by secondary fermentation with different starter cultures during storage.

\section{Materials and methods}

\section{Materials}

Kefir grains were obtained from the Dairy Technology Department of the Agriculture Faculty of Ankara University (Turkey). Kefir grains were inoculated into pasteurized semi-fat ( $1.5 \%)$ cow milk and incubated at $25^{\circ} \mathrm{C}$. The grains were transferred three times per week. Starter cultures used for secondary fermentation were purchased from $\mathrm{Chr}$. Hansen (Denmark): YC-350 (Streptococcus thermophilus, Lactobacillus delbrueckii subsp. bulgaricus) was used as a thermophilic culture, CHN-22 (Lactococcus subsp., Leuconostoc subsp.) was used as a mesophilic-aromatic culture, and La-5 (Lactobacillus acidophilus) and Bb-12 (Bifidobacterium lactis) were used as a probiotic culture. Saccharomyces cerevisiae (baker's yeast from Kent, Turkey) was used in this study.

\section{Methods}

\section{Production of kefir}

Kefir production method and parameters were given in Figure 1 and Table 1.

The kefirs were sampled in duplicate after 1, 5, 10,16 , and 23 days of refrigerated storage. The appropriate starting $\mathrm{pH}$ values, starter culture inoculation rates, and incubation temperatures for secondary fermentation were determined in preliminary experiments.

\section{Microbiological analysis}

Ringer tablets (Merck, Germany) at a concentration of 1 unit/L were used to prepare the dilutions for microbiological analyses. Lactobacillus counts were estimated on Rogosa Agar (Merck) medium at $30{ }^{\circ} \mathrm{C}$ under anaerobic conditions (anaerobic jar) for 48-72 h. Lactococcal counts were determined on M17 (Merck) medium at $37{ }^{\circ} \mathrm{C}$ for $48-72 \mathrm{~h}$ and Leuconostoc counts on leuconostoc-selective agar at $28-30{ }^{\circ} \mathrm{C}$ for $48 \mathrm{~h}$, respectively. Leuconostoc-selective agar was prepared according to Atlas (1997) and consisted of calcium carbonate $50 \mathrm{~g} / \mathrm{L}$; extract of malt $50 \mathrm{~g} / \mathrm{L}$; agar $15 \mathrm{~g} / \mathrm{L} ; \mathrm{NaCl} 2.5 \mathrm{~g} / \mathrm{L}$; extract of meat $1 \mathrm{~g} / \mathrm{L}$; poly-peptone from casein $1 \mathrm{~g} / \mathrm{L}$. Yeasts were grown on a Sabouraud dextrose + chloramphenicol agar (Merck) medium at $20-25{ }^{\circ} \mathrm{C}$ for 4-5 days. The numbers of viable bacteria or yeast cells are expressed as log colony-forming units per $\mathrm{mL}$ $(\log \mathrm{cfu} / \mathrm{mL})$. 


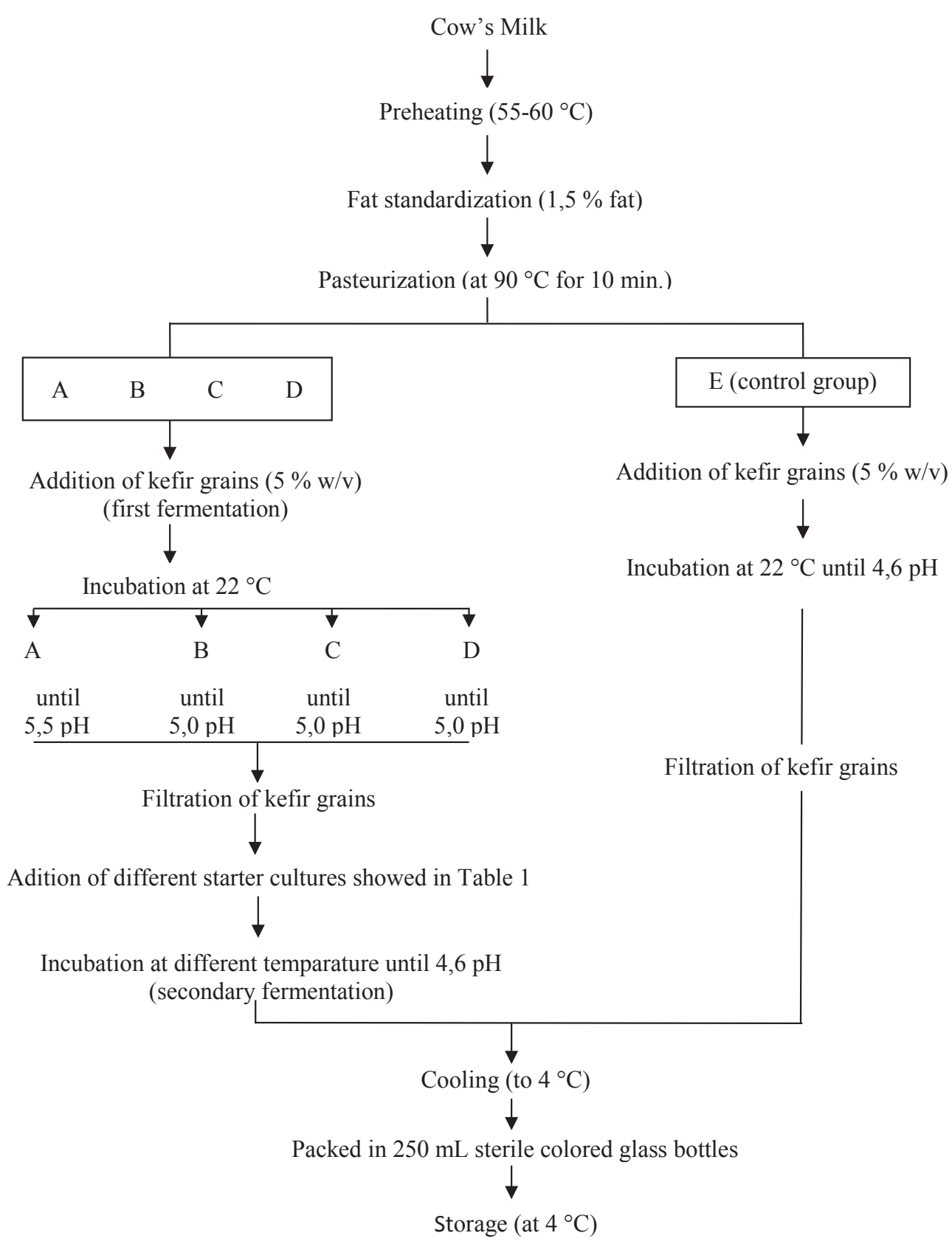

Figure 1. The diagram of kefir production

Table 1. The production parameters of kefir

\begin{tabular}{ccccccc}
\hline \multirow{2}{*}{ Samples } & \multicolumn{3}{c}{ First fermentation } & \multicolumn{3}{c}{ Secondary fermentation } \\
\cline { 2 - 7 } & $\begin{array}{c}\text { Incubation } \\
\text { temperature }\end{array}$ & $\begin{array}{c}\text { Incubation } \\
\mathrm{pH}\end{array}$ & $\begin{array}{c}\text { Starter culture and it's } \\
\text { rate }\end{array}$ & $\begin{array}{c}\text { Incubation } \\
\text { temperature }\end{array}$ & $\begin{array}{c}\text { Incubation } \\
\mathrm{pH}\end{array}$ & $\begin{array}{c}\text { Starter culture } \\
\text { and it's rate }\end{array}$ \\
\hline $\mathrm{A}$ & $22^{\circ} \mathrm{C}$ & $5.0 \mathrm{pH}$ & Kefir grain, $5 \% \mathrm{w} / \mathrm{v}$ & $32{ }^{\circ} \mathrm{C}$ & $4.6 \mathrm{pH}$ & Termophilic, $1 \%$ \\
\hline $\mathrm{B}$ & $22{ }^{\circ} \mathrm{C}$ & $5.5 \mathrm{pH}$ & Kefir grain, $5 \% \mathrm{w} / \mathrm{v}$ & $32{ }^{\circ} \mathrm{C}$ & $4.6 \mathrm{pH}$ & Probiotic, $5 \%$ \\
\hline $\mathrm{C}$ & $22{ }^{\circ} \mathrm{C}$ & $5.0 \mathrm{pH}$ & Kefir grain, $5 \% \mathrm{w} / \mathrm{v}$ & $22^{\circ} \mathrm{C}$ & $4.6 \mathrm{pH}$ & Mezophilic, $1 \%$ \\
\hline $\mathrm{D}$ & $22{ }^{\circ} \mathrm{C}$ & $5.0 \mathrm{pH}$ & Kefir grain, $5 \% \mathrm{w} / \mathrm{v}$ & $22^{\circ} \mathrm{C}$ & $4.6 \mathrm{pH}$ & Yeast, $0.5 \%$ \\
\hline $\mathrm{E}$ & $22{ }^{\circ} \mathrm{C}$ & $4.6 \mathrm{pH}$ & Kefir grain, $5 \% \mathrm{w} / \mathrm{v}$ & - & - & - \\
\hline
\end{tabular}




\section{Physicochemical analysis}

The physicochemical composition of each kefir sample was determined using standard methods: the Gerber method for fat (Anonymous, 1989), a gravimetric method for total dry matter (Anonymous, 1989) and the micro-Kjeldahl method for the total nitrogen content (IDF, 1993; AOAC, 2000). The protein content of the samples was calculated by multiplying the total nitrogen value by the conversion factor of 6.38 . The $\mathrm{pH}$ values were determined using a digital $\mathrm{pH}$ meter equipped with a combined electrode (Mettler Toledo, Switzerland). Viscosity measurements were carried out at $3{ }^{\circ} \mathrm{C}$ using a rotational viscometer (Haake Viscotester 181/ VTR 24, Germany) equipped with MV II spindle, at $60 \mathrm{rpm}(50 \mathrm{~Hz} / 60 \mathrm{Mz})$. The lactic acid (Steinsholt and Calbert, 1960) and tyrosine (Hull, 1947) contents of kefir samples were determined using spectrophotometric methods. The carbon dioxide content of the samples was analyzed using titrimetric methods (Anonymous, 1976).

\section{Determination of volatile aroma compounds}

The amounts of acetaldehyde, acetone, 2-butanone, ethanol, and diacetyl present in kefir samples were determined using the headspace method described by Ulbert (1991). Accordingly the kefir sample was homogenized and a 5-g thereof was weighed into a headspace vial. The samples were kept in an oven at $70{ }^{\circ} \mathrm{C}$ for $20 \mathrm{~min}$, then the air in the headspace of the vials $(1000 \mu \mathrm{L})$ was injected into a gas chromatograph (Agilent 6890 series, Agilent Technologies Inc., CA, USA) equipped with splitless inlet and a polyethylene glycol capillary column (30 $\mathrm{m} \times 320 \mu \mathrm{m} \times 0.25 \mu \mathrm{m}$; 19091-113 INNOWAX; Agilent Technologies) using a gas-tight syringe. Nitrogen (flow rate, $0.7 \mathrm{~mL} / \mathrm{min}$ ) was used as the carrier gas. The injection temperature was $80^{\circ} \mathrm{C}$. At the beginning of each analysis, the column temperature was kept at $50^{\circ} \mathrm{C}$ for $0.5 \mathrm{~min}$, then was raised from $50{ }^{\circ} \mathrm{C}$ to $70{ }^{\circ} \mathrm{C}$ at a rate of $4{ }^{\circ} \mathrm{C} \mathrm{min}^{-1}$ and held $0.5 \mathrm{~min}$, from $70^{\circ} \mathrm{C}$ to $180^{\circ} \mathrm{C}$ at a rate of $20{ }^{\circ} \mathrm{C}$ and held $0.2 \mathrm{~min}$. Flame ionization detector (FID) signals were stored using computer software (Agilent 6890 series Chemstation, Hewlett Packard Corp., Wilmington, DE).

\section{Sensory analysis}

Kefir beverages were submitted for sensory evaluation by ten panelists (selected from the members of the University staff who had previous taste panel experience and trained about kefir sensory evaluation). Samples were described using a hedonic scale by Bodyfelt et al. (1988). The sensory evaluation tests were performed in a room with controlled temperature and lighting conditions. The panelists consumed about $100 \mathrm{~mL}$ of kefir beverage at $10{ }^{\circ} \mathrm{C}$ in disposable plastic cup. Beside the kefir samples, crackers were served to panelists. The kefir samples were evaluated using a 10-point scale, with a score of 10 indicating the most liked and a score of 1 indicating the most disliked. The attributes were tasteflavor, consistency, and acceptability of the kefir.

\section{Statistical analysis}

Statistical analyses were performed by Analysis of variance (ANOVA) using Minitab statistical software (13.0) (Pennsylvania State Collage, 16801, USA). ANOVA with $95 \%$ confidence intervals was performed on each physicochemical and microbiological variable to detect possible differences among the samples for the two factors "starter culture" and "storage time". Significant differences between means were determined using Duncan's multiple range test; values of $\mathrm{p}<0.05$ were considered significant. Three replicates of all physicochemical and microbiological analyses were carried out for each kefir sample.

\section{Results and discussion}

\section{Microbiological analyses}

The changes in microbial population that occurred during storage of kefir samples are shown in Fig. 2. The lactobacilli, lactococcal and leuconostoc counts in all samples increased until day 5 of storage. This was followed by an approximately 2- to 3-log decline. This finding is consistent with those reported by other researchers (Wszolek et al., 2001; Ertekin and Guzel-Seydim, 2010). Irigoyen et al., (2005) reported that the lactobacilli and lactococcal counts started to decrease after production. 


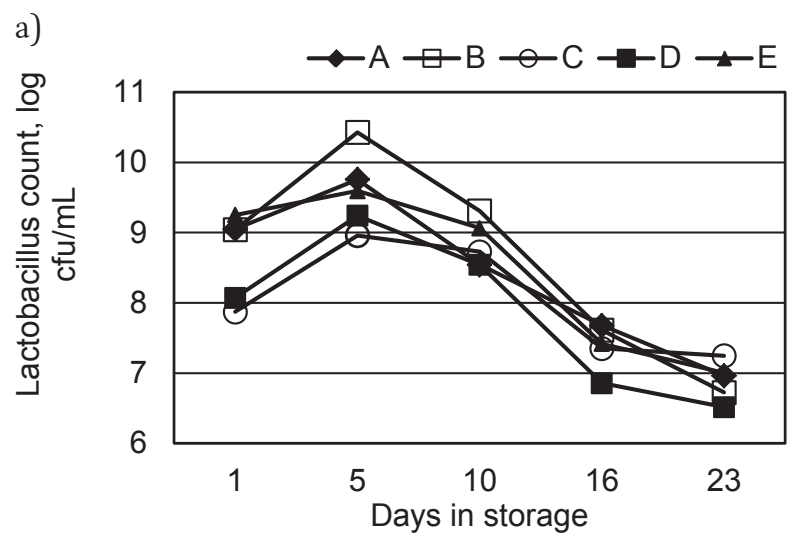

b)

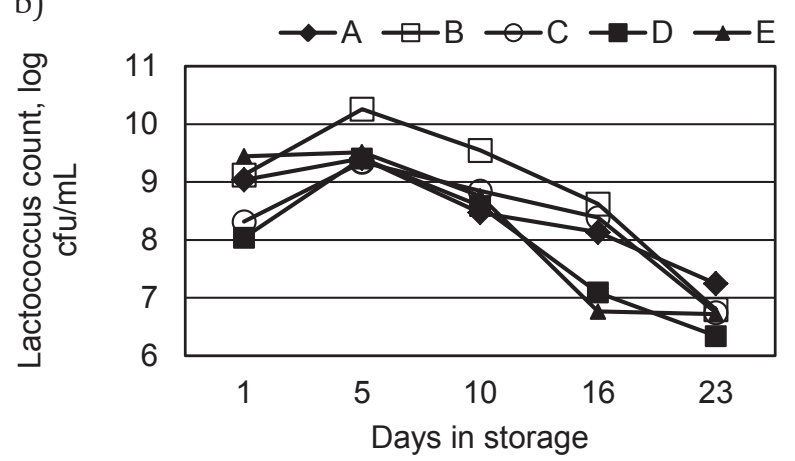

c)

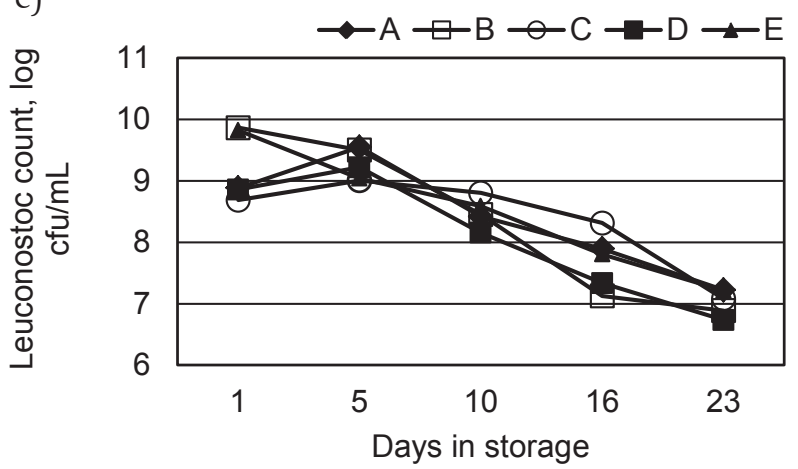

d)

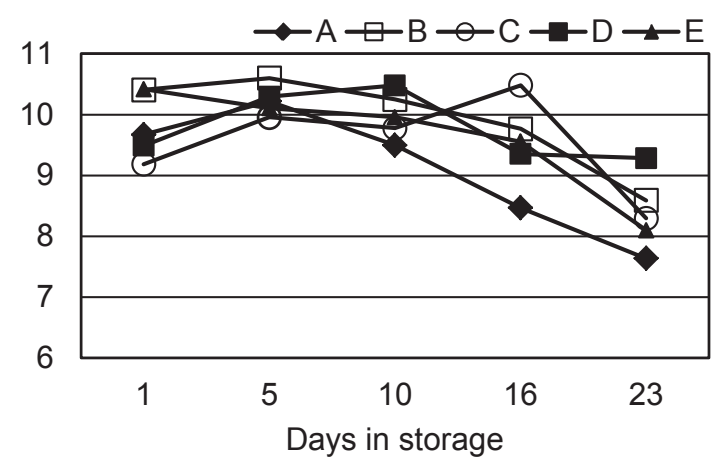

Figure 2. Microbial counts of kefir samples.

(a) Lactobacillus, (b) Lactococcus,

(c) Leuconostoc, and (d) yeast
The highest lactobacilli counts (10.4 log $\mathrm{cfu} / \mathrm{mL}$ ) were found in sample $\mathrm{B}$ during the storage. It was followed by samples A $(9.7 \log \mathrm{cfu} / \mathrm{mL})$, E (9.5 log cfu/mL), D (9.2 log cfu/mL) and C (8.9 log cfu/mL). Samples A and B contained lactobacilli originating from kefir grains in the first fermentation, as well as from starter cultures used in the secondary fermentation. In contrast to that, lactobacilli in the other samples $(\mathrm{C}, \mathrm{D}, \mathrm{E})$ originated only from the kefir grains. Although the samples A and $\mathrm{E}$ were close to each other, the difference between lactobacilli counts during the storage was significant $(p<0.01)$. The values determined in this study are higher than those obtained by Koroleva (1982) and lower than those of Beshkova et al., (2002) and Dinkçi et al., (2015), but they are similar to the values obtained by others (GüzelSeydim et al., 2005; Irigoyen et al., 2005; Ertekin and Guzel-Seydim, 2010).

Regarding the lactococci count, while sample B contained the highest level $(10.2 \log \mathrm{cfu} / \mathrm{mL})$, there were no differences among other samples (about $9.5 \log \mathrm{cfu} / \mathrm{mL}$ ) after 5 days of storage. These results are consistent with the findings of Kilic et al., (1999) and are slightly higher than the levels reported by other researchers (Irigoyen et al., 2005; Dinkçi et al., 2015). However, they are lower than those reported by Beshkova et al. (2002) and Kesenkas et al. (2011). This bacterial group followed the same general pattern as the lactobacilli. At the end of the storage period, the differences among the lactococci counts of the samples were statistically significant $(\mathrm{p}<0.01)$. During the storage period, the greatest decrease was observed in sample D.

Leuconostoc sp. levels in samples A, C, D, and E increased up to day 5 of storage and then declined; whereas, sample B showed a decrease in leuconostoc counts from the beginning to the end of storage. At the end of the storage period, the differences among the samples were not statistically significant ( $p>0.05)$. During storage, the greatest decreases in lactobacilli, lactococci and leuconostoc levels, which were statistically significant $(\mathrm{p}<0.05)$, generally took place from days 5 to 14. Levels of these bacteria remained nearly constant over the remainder of the storage period. The decrease in lactic acid bacterial counts during the storage period is probably due to a rise in the acidity and the alcohol content of kefir samples (Ayhan et al., 2005). 
In this study, non-lactose-fermenting Saccharomyces cerevisiae was used as the yeast starter culture for the production of sample D. The highest yeast counts were observed in samples $\mathrm{B}$ and $\mathrm{D}(10.1$ and $10.06 \log \mathrm{cfu} / \mathrm{mL}$ ) followed by samples $\mathrm{C}, \mathrm{A}$, and $\mathrm{E}$. The yeast levels in kefir samples were higher than those reported by other researchers (Irigoyen et al., 2005; Kesenkaş et al., 2011; Dinkci et al., 2015). Counts in samples $A$ and $D$ were virtually constant up to day 10 of storage, and up to day 5 of storage in samples $B, C$, and $E$, with no significant differences $(p>0.05)$. Thereafter, the yeast counts decreased.

\section{Proximate chemical composition}

The composition of kefir is variable and depends on the composition of grains or mixture of cultures, and the applied technological process. The chemical compositions of kefir samples produced in this study are shown in Table 2.

There were no significant differences among kefir samples with respect to their dry matter contents. The variations that occurred during storage were also not statistically significant $(\mathrm{p}>0.05)$. Secondary fermentation did not influence the dry matter content of kefir because that factor depended on the milk used in the production rather than the fermentation process (Irigoyen et al., 2005). The dry matter contents of all samples were between $9.78 \%$ and $9.98 \%$ at the end of the storage period.

The $\mathrm{pH}$ values declined in all samples slightly during the storage period ( $p>0.05)$ (Table 2). The $\mathrm{pH}$ of fermented milk declines with storage time because lactic acid bacteria produce organic acids using lactose (Katsiari et al., 2002). Unlike other fermented milk products, the $\mathrm{pH}$ of kefir did not significantly vary during storage, probably because of the present yeasts. Lactic acid bacteria grow and produce organic acids more slowly in the presence of yeasts rather than in pure cultures (Collar, 1996). At the end of the storage period, the lowest decrease in $\mathrm{pH}$ was observed in sample A (thermophilic culture). There were no significant differences among other samples $(p>0.05)$. Changes in the patterns of $\mathrm{pH}$ and titratable acidity observed in our study were in agreement with previous findings of many researchers (Beshkova et al., 2002; Güzel-Seydim et al., 2005; Cais-Sokolinska et al., 2008; Sady et al., 2009; Dinkci et al., 2015).
Our results indicate that the type of starter culture used had a significant effect on the lactic acid content of the kefir samples $(\mathrm{p}<0.05)$. The highest lactic acid content was observed in sample $C$. The lactic acid contents of the secondary-fermentation samples were between 0.461 and $0.672 \mathrm{~g} / 100 \mathrm{~g}$, whereas that of the traditionally-produced kefir sample (E) was between 0.466 and $0.581 \mathrm{~g} / 100 \mathrm{~g}$. The differences among the lactic acid contents of the samples were due to the diversity of lactic acid production capabilities of the cultures used for secondary fermentation. The lactic acid content of the kefir samples consistently increased during the storage period and was the most in sample $E$, followed by samples B, D, A, and C. These values were lower than those observed by Kin1k et al., (1998), but were higher than the values reported by Muir et al., (1999). Moreover, the lactic acid content of the kefir produced by the traditional method (sample E) was lower than that obtained by Muir et al. (1999).

As shown in Table 2, there were no statistically significant differences among the protein contents of kefir samples ( $p>0.05)$. Protein contents of the samples were between $3.11 \%$ and $3.29 \%$, which was similar to the values reported by Muir et al., (1999). Also, it was found that protein contents of kefir samples did not change significantly $(p>0.05)$ during the storage period.

The tyrosine contents of samples A, B, C, D, and $\mathrm{E}$ increased throughout the storage period and reached $0.125,0.140,0.116,0.116$, and $0.093 \mathrm{mg} / 5 \mathrm{~g}$, respectively, by the end of the storage period (Table 2). The differences among kefir samples were found to be statistically significant $(p<0.05)$. The tyrosine levels in samples A, D and E were similar to each other $(p>0.05)$, but differed from those of samples B and C $(p<0.05)$. The highest tyrosine content was obtained in samples B (with probiotic culture) and $\mathrm{C}$ (with mesophilic aromatic culture). The starter culture had an important effect on the tyrosine content due to differences in proteolytic activities (Rasic and Kurman 1978). Özer et al. (2000) reported that the tyrosine contents of kefir samples produced by different methods varied between 0.362 and $0.568 \mathrm{mg} / \mathrm{mL}$.

Like tyrosine, carbon dioxide levels in all samples also increased during the storage. The highest carbon dioxide content was observed in sample $\mathrm{D}$, because it contained yeasts from kefir grains as 
Table 2. Changes in the chemical properties of the kefir samples*

\begin{tabular}{|c|c|c|c|c|c|c|}
\hline Properties & Day & A & B & $\mathrm{C}$ & $\mathrm{D}$ & $\mathrm{E}$ \\
\hline \multirow{6}{*}{$\begin{array}{c}\text { Dry matter } \\
(\%)\end{array}$} & 1 & $9.91 \pm 0.19$ & $9.95 \pm 0.33$ & $9.94 \pm 0.37$ & $9.98 \pm 0.34$ & $9.93 \pm 0.24$ \\
\hline & 5 & $9.95 \pm 0.23$ & $10.01 \pm 0.30$ & $9.95 \pm 0.31$ & $9.99 \pm 0.28$ & $9.99 \pm 0.30$ \\
\hline & 10 & $10.00 \pm 0.25$ & $9.91 \pm 0.31$ & $9.92 \pm 0.34$ & $9.92 \pm 0.31$ & $9.87 \pm 0.28$ \\
\hline & 16 & $9.6 \pm 0.23$ & $9.86 \pm 0.28$ & $9.89 \pm 0.34$ & $9.82 \pm 0.34$ & $9.86 \pm 0.32$ \\
\hline & 23 & $9.78 \pm 0.25$ & $9.78 \pm 0.30$ & $9.98 \pm 0.34$ & $9.94 \pm 0.38$ & $9.82 \pm 0.28$ \\
\hline & $\mathrm{P}^{* *}$ & ns & ns & ns & ns & $\mathrm{ns}$ \\
\hline \multirow{6}{*}{$\mathrm{pH}$ value } & 1 & $4.50 \pm 0.10$ & $4.43 \pm 0.09$ & $4.46 \pm 0.14$ & $4.48 \pm 0.03$ & $4.44 \pm 0.03$ \\
\hline & 5 & $4.47 \pm 0.09$ & $4.33 \pm .0 .06$ & $4.37 \pm 0.08$ & $4.39 \pm 0.08$ & $4.36 \pm 0.07$ \\
\hline & 10 & $4.41 \pm 0.06$ & $4.29 \pm 0.03$ & $4.28 \pm 0.07$ & $4.32 \pm 0.05$ & $4.33 \pm 0.05$ \\
\hline & 16 & $4.35 \pm 0.02$ & $4.25 \pm 0.02$ & $4.23 \pm 0.05$ & $4.26 \pm 0.04$ & $4.27 \pm 0.06$ \\
\hline & 23 & $4.31 \pm 0.01$ & $4.19 \pm 0.01$ & $4.19 \pm 0.05$ & $4.21 \pm 0.03$ & $4.25 \pm 0.03$ \\
\hline & $\mathrm{p}$ & $\mathrm{A}$ & B & B & B & B \\
\hline \multirow{6}{*}{$\begin{array}{c}\text { Lactic acid } \\
\text { (g/100 g) }\end{array}$} & 1 & $0.515 \pm 0.02$ & $0.491 \pm 0.02$ & $0.648 \pm 0.01$ & $0.461 \pm 0.01$ & $0.466 \pm 0.01$ \\
\hline & 5 & $0.545 \pm 0.01$ & $0.500 \pm 0.02$ & $0.662 \pm 0.02$ & $0.480 \pm 0.01$ & $0.486 \pm 0.02$ \\
\hline & 10 & $0.585 \pm 0.01$ & $0.572 \pm 0.06$ & $0.672 \pm 0.02$ & $0.533 \pm 0.05$ & $0.585 \pm 0.09$ \\
\hline & 16 & $0.571 \pm 0.01$ & $0.560 \pm 0.05$ & $0.658 \pm 0.02$ & $0.507 \pm 0.07$ & $0.565 \pm 0.10$ \\
\hline & 23 & $0.567 \pm 0.01$ & $0.590 \pm 0.07$ & $0.669 \pm 0.01$ & $0.559 \pm 0.01$ & $0.581 \pm 0.09$ \\
\hline & $\mathrm{p}$ & B & $\mathrm{BC}$ & $\mathrm{A}$ & $\mathrm{C}$ & $\mathrm{BC}$ \\
\hline \multirow{6}{*}{ Protein (\%) } & 1 & $3.29 \pm 0.01$ & $3.24 \pm 0.02$ & $3.27 \pm 0.01$ & $3.29 \pm 0.01$ & $3.28 \pm 0.02$ \\
\hline & 5 & $3.20 \pm 0.04$ & $3.18 \pm 0.01$ & $3.21 \pm 0.03$ & $3.23 \pm 0.02$ & $3.22 \pm 0.07$ \\
\hline & 10 & $3.12 \pm 0.01$ & $3.11 \pm 0.01$ & $3.12 \pm 0.05$ & $3.15 \pm 0.01$ & $3.14 \pm 0.01$ \\
\hline & 16 & $3.23 \pm 0.03$ & $3.23 \pm 0.01$ & $3.23 \pm 0.03$ & $3.24 \pm 0.01$ & $3.28 \pm 0.03$ \\
\hline & 23 & $3.25 \pm 0.04$ & $3.26 \pm 0.01$ & $3.28 \pm 0.01$ & $3.25 \pm 0.01$ & $3.29 \pm 0.02$ \\
\hline & $\mathrm{p}$ & B & B & B & $\mathrm{AB}$ & $\mathrm{A}$ \\
\hline \multirow{6}{*}{$\begin{array}{l}\text { Tyrosine } \\
\mathrm{mg} / 5 \mathrm{~g}\end{array}$} & 1 & $0.305 \pm 0.002$ & $0.307 \pm 0.005$ & $0.329 \pm 0.001$ & $0.303 \pm 0.013$ & $0.333 \pm 0.02$ \\
\hline & 5 & $0.365 \pm 0.009$ & $0.349 \pm 0.03$ & $0.361 \pm 0.03$ & $0.332 \pm 0.005$ & $0.363 \pm 0.02$ \\
\hline & 10 & $0.405 \pm 0.03$ & $0.383 \pm 0.05$ & $0.409 \pm 0.07$ & $0.369 \pm 0.03$ & $0.398 \pm 0.02$ \\
\hline & 16 & $0.415 \pm 0.03$ & $0.426 \pm 0.06$ & $0.438 \pm 0.04$ & $0.391 \pm 0.03$ & $0.412 \pm 0.03$ \\
\hline & 23 & $0.430 \pm 0.03$ & $0.447 \pm 0.05$ & $0.445 \pm 0.04$ & $0.419 \pm 0.02$ & $0.426 \pm 0.03$ \\
\hline & $\mathrm{p}$ & B & $\mathrm{A}$ & $\mathrm{A}$ & B & B \\
\hline \multirow{6}{*}{$\underset{(\mathrm{mg} / \mathrm{l} 00 \mathrm{~mL})}{\mathrm{CO}_{2}}$} & 1 & $57.93 \pm 4.9$ & $92.70 \pm 49.0$ & $109.50 \pm 25.3$ & $111.40 \pm 25.5$ & $54.40 \pm 27.6$ \\
\hline & 5 & $78.73 \pm 10.1$ & $106.10 \pm 39.4$ & $119.90 \pm 29.0$ & $122.00 \pm 21.5$ & $75.60 \pm 24.3$ \\
\hline & 10 & $92.40 \pm 18.4$ & $118.40 \pm 30.9$ & $128.00 \pm 28.7$ & $138.80 \pm 19.2$ & $86.20 \pm 23.6$ \\
\hline & 16 & $104.40 \pm 15.9$ & $132.80 \pm 22.3$ & $138.30 \pm 22.6$ & $148.53 \pm 17.2$ & $98.60 \pm 18.6$ \\
\hline & 23 & $119.20 \pm 18.5$ & $143.97 \pm 15.7$ & $148.30 \pm 18.6$ & $158.67 \pm 13.5$ & $108.40 \pm 18.2$ \\
\hline & $\mathrm{p}$ & B & $\mathrm{A}$ & $\mathrm{A}$ & $\mathrm{A}$ & B \\
\hline \multirow{6}{*}{$\begin{array}{c}\text { Viscosity } \\
\text { (mPas) }\end{array}$} & 1 & $66.0 \pm 27$ & $144.0 \pm 18$ & $115.6 \pm 4$ & $79.7 \pm 28$ & $70.7 \pm 43$ \\
\hline & 5 & $66.8 \pm 26$ & $136.0 \pm 7$ & $135.0 \pm 0$ & $94.7 \pm 37$ & $78.0 \pm 48$ \\
\hline & 10 & $70.7 \pm 25$ & $130.0 \pm 4$ & $129.0 \pm 9$ & $72.0 \pm 27$ & $61.7 \pm 34$ \\
\hline & 16 & $73.7 \pm 31$ & $142.3 \pm 13$ & $127.3 \pm 1$ & $93.0 \pm 45$ & $85.7 \pm 52$ \\
\hline & 23 & $63.8 \pm 27$ & $141.0 \pm 15$ & $120.0 \pm 0$ & $81.8 \pm 41$ & $70.7 \pm 46$ \\
\hline & $\mathrm{P}^{* *}$ & B & $\mathrm{A}$ & $\mathrm{A}$ & B & B \\
\hline
\end{tabular}

*Values in this table are the mean of 3 replicates \pm SEM. Treatments:

A: $5 \%(\mathrm{w} / \mathrm{v})$ kefir grain $+1 \%$ thermophilic culture (Streptococcus thermophilus, Lactobacillus delbrueckii subsp. bulgaricus);

B: $5 \%(\mathrm{w} / \mathrm{v})$ kefir grain $+5 \%$ probiotic culture (Lactobacillus acidophilus, Bifidobacterium lactis);

C: $5 \%(\mathrm{w} / \mathrm{v})$ kefir grain $+1 \%$ mesophilic culture (Lactococcus spp., Leuconostoc spp.);

D: $5 \%(\mathrm{w} / \mathrm{v})$ kefir grain $+0.5 \%$ yeast culture (Saccharomyces cerevisiae);

E: $5 \%(w / v)$ kefir grain (control sample)

${ }^{* *}$ The differences between the means of the samples on the same line are statistically significant at the $\mathrm{p}<0.05$ level

Different groups are indicated by different capital letters. 
well as from the secondary fermentation. Statistical evaluation of the carbon dioxide contents revealed that samples B, C, and D differed from samples A and $\mathrm{E}(\mathrm{p}<0.05)$. That difference was due to the starter culture used for secondary fermentation. Probiotic cultures (Lactobacillus acidophilus, Bifidobacterium lactis), mesophilic aromatic cultures (Leuconostoc subsp.) and yeasts are heterofermentative microorganisms and produce carbon dioxide in addition to organic acids. Thermophilic cultures (Streptococcus thermophilus, Lactobacillus delbrueckii subsp. bulgaricus) either cannot produce carbon dioxide or produce only very low levels, depending on the strain used.

The viscosities of kefir samples showed a tendency to increase or decrease during the storage period (Table 2) which was similar to findings of Irigoyen et al., (2005). The differences among viscosities of samples were found to be significant $(p<0.05)$. Like tyrosine content, the viscosities of samples A, D and E were similar $(p>0.05)$, but differed from those of samples B and $C(p<0.05)$. The highest viscosities were observed in samples $B$ and C, followed by samples D, E, and A. This result can be explained by the acid production and proteolytic activities of the secondary starter cultures used in the production of kefir. Briefly, the secondary starter cultures had an important effect on the viscosity of the samples. The viscosity results correlated with those of the tyrosine and lactic acid contents of the samples. Similar increase (Sady et al., 2009) and decrease (Dinkci et al., 2015; Akal et al., 2016) tendency was reported in kefir samples during ripening by other researchers.

\section{Volatile aroma compounds}

Acetaldehyde is an important aroma component of fermented products like yogurt (Beshkova et al., 1998). The amount of acetaldehyde present in fermented beverages has been reported to increase initially during storage, but it decreases after the first two weeks (Ott et al., 1999). The opposite is the case in kefir samples since the amount of acetaldehyde continues to increase along with the progress of storage. Table 3 shows that the amount of acetaldehyde in kefir samples ranged from 6.09 to $11.90 \mathrm{ppm}$. Although the acetaldehyde content declined in some samples at times during storage, the acetaldehyde content at the end of the storage period was greater than the initial amount. The highest acetaldehyde content was obtained in kefir sample E, which was produced by the traditional method. Sample E was followed by sample A, which contained a thermophilic culture. Statistical evaluation revealed that the acetaldehyde content of each sample was different at days 1 and 23 of storage $(p<0.05)$.

Güzel-Seydim et al., (2000b), determined that the average amount of acetaldehyde in kefir samples was $11 \mathrm{ppm}$ and it increased during 21 days of storage. Beshkova et al., (2003) incubated cow milk at $22{ }^{\circ} \mathrm{C}$ for $24 \mathrm{~h}$ and found that the therefrom resulting acetaldehyde level was $18.1 \mathrm{ppm}$. At the end of the storage period (7 days) acetaldehyde content decreased to $15.3 \mathrm{ppm}$. Similar results were reported by Ertekin and Guzel-Seydim (2010).

The acetone content of kefir samples ranged between 9.57 ppm and 12.58 ppm (Table 3) and was reduced in all samples at the end of storage. The highest acetone content was obtained from sample E (control sample), which was produced using a conventional method. The acetone contents of $A$ and $E$ were similar while the other samples (B, C, and D) were different $(p<0.05)$. Furthermore, differences between days 1 and 23 of storage were significant $(\mathrm{p}<0.05)$.

The butanone contents of kefir samples increased during storage but the observed increase was statistically insignificant ( $p>0.05)$. A statistical analysis of the mean butanone contents showed that all samples were similar, except sample A, which was significantly different $(\mathrm{p}<0.05)$ (Table 3$)$.

The ethanol content of kefir (Table 3) ranged from $1593 \mathrm{ppm}$ to $3381 \mathrm{ppm}$. The ethanol levels in all samples increased during storage, although they usually showed different trends. The ethanol contents were found to differ from each other on storage days 1 and $23(\mathrm{p}<0.05)$. The sample with the highest ethanol content on all days except day 23 of storage was kefir D, which contained the yeast culture $(\mathrm{p}<0.05)$. Yeast is mainly responsible for the alcohol production in kefir. Although yeast is generally characterized by the ability to produce ethanol, the Lactobacillus strains in kefir are heterofermentative and have the ability to produce both, ethanol (up to $0.25 \%)$ and carbon dioxide (Marshall, 1984). 
Diacetyl is another important carbonyl component in the formation of flavour. Excessive amounts of diacetyl in fermented beverages are known to cause the formation of a hard and sharp taste (Ott et al., 2000). In this study, the diacetyl content ranged from 0.0 to $13.68 \mathrm{ppm}$. Diacetyl was observed in some of the samples on the first day of storage, but it could not be detected in following days (Table 3).
This could probably be explained by the ability of lactic acid bacteria to produce a diacetyl reductase enzyme that transforms to diacetyl into acetone and 2,3-butylene glycol (Cais-Sokolinska, 2008). Güzel-Seydim et al., (2000b) could not detect diacetyl neither during fermentation nor during storage of kefir.

Table 3. Volatile aroma compounds (ppm) of kefir samples*

\begin{tabular}{|c|c|c|c|c|c|c|}
\hline \multirow{2}{*}{ Compounds } & \multirow{2}{*}{ Day } & \multicolumn{5}{|c|}{ Treatment } \\
\hline & & $\mathrm{A}$ & $\mathrm{B}$ & $\mathrm{C}$ & $\mathrm{D}$ & E \\
\hline \multirow{6}{*}{ Acetaldehyde } & 1 & $6.59 \pm 0.62^{b}$ & $6.88 \pm 0.41^{\mathrm{b}}$ & $6.84 \pm 0.38^{\mathrm{b}}$ & $6.09 \pm 0.90^{b}$ & $7.0 \pm 0.41^{\mathrm{b}}$ \\
\hline & 5 & $9.45 \pm 0.80^{\mathrm{ab}}$ & $7.22 \pm 1.40^{\mathrm{b}}$ & $8.93 \pm 1.91^{\mathrm{ab}}$ & $8.81 \pm 1.16^{\mathrm{a}}$ & $10.96 \pm 0.95^{\mathrm{a}}$ \\
\hline & 10 & $11.01 \pm 1.70^{\mathrm{a}}$ & $9.03 \pm 1.62^{\mathrm{ab}}$ & $9.50 \pm 0.41^{\mathrm{a}}$ & $8.50 \pm 2.73^{a}$ & $8.90 \pm 1.40^{\mathrm{ab}}$ \\
\hline & 16 & $10.98 \pm 0.77^{\mathrm{a}}$ & $9.80 \pm 1.82^{\mathrm{a}}$ & $7.24 \pm 0.64^{\mathrm{ab}}$ & $9.00 \pm 2.31^{\mathrm{a}}$ & $9.78 \pm 0.46^{\mathrm{a}}$ \\
\hline & 23 & $9.44 \pm 0.75^{\mathrm{ab}}$ & $10.22 \pm 1.01^{\mathrm{a}}$ & $9.92 \pm 1.74^{\mathrm{a}}$ & $9.36 \pm 1.62^{\mathrm{a}}$ & $11.90 \pm 0.64^{\mathrm{a}}$ \\
\hline & $P$ & $\mathrm{~A}$ & B & B & B & $\mathrm{A}$ \\
\hline \multirow{6}{*}{ Acetone } & 1 & $10.61 \pm 0.57^{\mathrm{a}}$ & $10.56 \pm 0.56^{\mathrm{a}}$ & $10.93 \pm 0.45^{\mathrm{a}}$ & $10.96 \pm 0.70^{\mathrm{a}}$ & $12.58 \pm 0.81^{\mathrm{a}}$ \\
\hline & 5 & $10.62 \pm 0.40^{\mathrm{a}}$ & $9.72 \pm 0.56^{\mathrm{b}}$ & $10.51 \pm 0.52^{\mathrm{a}}$ & $9.88 \pm 0.72^{b}$ & $11.17 \pm 0.73^{\mathrm{ab}}$ \\
\hline & 10 & $10.65 \pm 0.49^{a}$ & $9.86 \pm 0.58^{b}$ & $10.56 \pm 0.21^{a}$ & $9.99 \pm 0.57^{b}$ & $11.11 \pm 0.37^{\mathrm{ab}}$ \\
\hline & 16 & $10.59 \pm 1.03^{\mathrm{a}}$ & $9.92 \pm 0.74^{b}$ & $9.58 \pm 0.41^{b}$ & $9.90 \pm 0.31^{b}$ & $10.58 \pm 0.82^{\mathrm{b}}$ \\
\hline & 23 & $9.62 \pm 0.15^{b}$ & $9.57 \pm 0.04^{\mathrm{b}}$ & $9.61 \pm 0.24^{b}$ & $9.79 \pm 0.40^{\mathrm{b}}$ & $10.86 \pm 1.02^{\mathrm{b}}$ \\
\hline & $\mathrm{p}$ & $\mathrm{AB}$ & B & B & B & $\mathrm{A}$ \\
\hline \multirow{6}{*}{ Butanone } & 1 & $11.03 \pm 0.58^{\mathrm{b}}$ & $10.76 \pm 0.45$ & $10.34 \pm 0.14$ & $10.41 \pm 0.29$ & $10.46 \pm 0.47$ \\
\hline & 5 & $12.05 \pm 0.53^{\mathrm{ab}}$ & $11.24 \pm 1.14$ & $10.72 \pm 1.82$ & $11.58 \pm 2.58$ & $10.71 \pm 0.87$ \\
\hline & 10 & $13.04 \pm 0.82^{\mathrm{a}}$ & $11.31 \pm 0.81$ & $10.82 \pm 1.43$ & $10.80 \pm 1.16$ & $10.81 \pm 0.49$ \\
\hline & 16 & $12.57 \pm 0.86^{\mathrm{ab}}$ & $11.18 \pm 1.45$ & $10.60 \pm 0.91$ & $10.94 \pm 1.27$ & $11.63 \pm 1.47$ \\
\hline & 23 & $12.73 \pm 0.45^{\mathrm{ab}}$ & $11.88 \pm 0.90$ & $10.63 \pm 0.74$ & $11.18 \pm 1.13$ & $11.95 \pm 1.45$ \\
\hline & $\mathrm{p}$ & $\mathrm{A}$ & B & B & B & B \\
\hline \multirow{6}{*}{ Ethanol } & 1 & $1593 \pm 517^{c}$ & $1600 \pm 186^{c}$ & $1703 \pm 701^{\mathrm{c}}$ & $2552 \pm 208^{\mathrm{b}}$ & $2110 \pm 679^{\mathrm{ab}}$ \\
\hline & 5 & $2635 \pm 143^{b}$ & $1854 \pm 183^{c}$ & $2067 \pm 673^{b}$ & $2755 \pm 339^{b}$ & $1868 \pm 330^{b}$ \\
\hline & 10 & $2549 \pm 148^{b}$ & $2383 \pm 218^{b}$ & $2137 \pm 382^{b}$ & $2881 \pm 240^{\mathrm{ab}}$ & $2587 \pm 209^{a}$ \\
\hline & 16 & $2908 \pm 91^{b}$ & $2597 \pm 325^{b}$ & $1967 \pm 855^{\mathrm{cb}}$ & $3048 \pm 468^{a}$ & $2382 \pm 407^{a}$ \\
\hline & 23 & $3381 \pm 352^{a}$ & $2652 \pm 468^{a}$ & $2688 \pm 579^{a}$ & $3201 \pm 988^{a}$ & $2459 \pm 322^{a}$ \\
\hline & $\mathrm{p}$ & $\mathrm{A}$ & B & B & $\mathrm{A}$ & B \\
\hline \multirow{5}{*}{ Diacetyl } & 1 & $11.29 \pm 1.22$ & $10.87 \pm 0.55$ & $13.68 \pm 3.47$ & $7.18 \pm 6.21$ & $12.07 \pm 1.14$ \\
\hline & 5 & $11.74 \pm 1.15$ & $10.63 \pm 0.20$ & $11.23 \pm 0.95$ & $7.42 \pm 6.43$ & $11.73 \pm 0.83$ \\
\hline & 10 & $11.53 \pm 0.90$ & $10.59 \pm 0.25$ & $10.84 \pm 0.59$ & $7.17 \pm 6.21$ & $11.78 \pm 1.02$ \\
\hline & 16 & $11.27 \pm 1.44$ & $7.45 \pm 6.51$ & $10.41 \pm 0.09$ & $0.00 \pm 0.00$ & $11.85 \pm 1.41$ \\
\hline & 23 & $10.83 \pm 0.51$ & $6.92 \pm 6.00$ & $10.93 \pm 0.53$ & $0.00 \pm 0.00$ & $11.63 \pm 1.41$ \\
\hline
\end{tabular}

*Values in this table are the mean of 3 replicates \pm SEM. Treatments:

A: $5 \%(\mathrm{w} / \mathrm{v})$ kefir grain $+1 \%$ thermophilic culture (Streptococcus thermophilus, Lactobacillus delbrueckii subsp. bulgaricus);

B: $5 \%(\mathrm{w} / \mathrm{v})$ kefir grain $+5 \%$ probiotic culture (Lactobacillus acidophilus, Bifidobacterium lactis);

C: $5 \%$ (w/v) kefir grain $+1 \%$ mesophilic culture (Lactococcus spp., Leuconostoc spp.);

D: $5 \%(\mathrm{w} / \mathrm{v})$ kefir grain $+0.5 \%$ yeast culture (Saccharomyces cerevisiae);

E: $5 \%(\mathrm{w} / \mathrm{v})$ kefir grain (control sample)

$\mathrm{a}, \mathrm{b}$ means in the same column with different letters were significantly affected by storage

${ }^{A-B}$ means in the same row with different capital letters were significantly affected by treatments $(p<0.05)$ 


\section{Sensory analyses}

The sensory properties of foods are useful as quality control criteria. To assess their sensory properties, the kefir samples were evaluated for tasteflavour, consistency and acceptability. The results of the sensory analysis are displayed in Table 4. Panelists rated samples A, B, C and D, which were produced by a secondary fermentation, higher than sample $\mathrm{E}$, which was produced using traditional methods (control) during storage. The taste-flavour scores of the control sample (E) were lower than those of other samples. These scores decreased along with the storage duration. Sample E differed from other samples, as well as from the overall average, and the differences were statistically significant $(p<0.05)$. The panelists commented that sample A (with a thermophilic culture) had a sour taste, similar to buttermilk, and that sample D (with a yeast culture) had a creamy or velvety taste. The panelists also reported that sample $\mathrm{C}$ (made with a mesophilic aromatic culture) caused a burning taste in the nasal fossae toward the end of storage. Sample E, which was produced by traditional methods, was insipid in taste and flavour.
Samples C and D received the highest score in terms of consistency, while that of sample E was the lowest one (Table 4$)$. There were significant differences $(p<0.01)$ among the consistency scores of samples. The consistencies of samples A and B were similar to that of Ayran (a drink made of yogurt, water, and salt) why the panelists preferred them to the other samples.

Among kefir samples produced by a secondary fermentation, sample $\mathrm{C}$ had the highest score whereas sample A had the lowest score for overall appreciation (Table 4). In general, the control sample was preferred the least by the panelists.

\section{Conclusion}

During 23 days of storage, the lactobacillus, lactoccoccal, leuconostoc, and yeast contents of the kefir samples increased up to day 5 of the storage and decreased thereafter. Although the $\mathrm{pH}$ decreased during storage, the lactic acid, tyrosine, and carbon dioxide contents increased. The viscosities of the samples showed both increases and decreases,

Table 4. Sensory characteristics of kefir samples*

\begin{tabular}{|c|c|c|c|c|c|c|}
\hline Properties & Day & A & B & $\mathrm{C}$ & $\mathrm{D}$ & E \\
\hline \multirow{6}{*}{ Taste-flavor } & 1 & $7.25 \pm 0.25$ & $7.43 \pm 0.43$ & $8.06 \pm 0.05$ & $8.13 \pm 0.90$ & $6.48 \pm 0.50$ \\
\hline & 5 & $7.82 \pm 0.38$ & $7.52 \pm 0.08$ & $8.09 \pm 0.80$ & $7.55 \pm 0.85$ & $5.80 \pm 0.34$ \\
\hline & 10 & $7.56 \pm 0.23$ & $7.05 \pm 0.75$ & $7.76 \pm 0.28$ & $7.53 \pm 0.60$ & $5.76 \pm 0.65$ \\
\hline & 16 & $7.35 \pm 0.64$ & $7.35 \pm 0.35$ & $7.45 \pm 0.14$ & $6.89 \pm 0.77$ & $5.58 \pm 0.69$ \\
\hline & 23 & $7.19 \pm 0.09$ & $7.24 \pm 0.04$ & $6.96 \pm 0.25$ & $6.90 \pm 0.70$ & $4.73 \pm 1.48$ \\
\hline & $\mathrm{P}^{* *}$ & A & A & A & A & B \\
\hline \multirow{6}{*}{ Consistency } & 1 & $7.57 \pm 0.32$ & $7.47 \pm 0.77$ & $8.05 \pm 0.70$ & $8.19 \pm 0.42$ & $6.65 \pm 1.31$ \\
\hline & 5 & $7.72 \pm 0.28$ & $7.53 \pm 0.13$ & $7.95 \pm 0.27$ & $7.57 \pm 0.54$ & $6.47 \pm 0.81$ \\
\hline & 10 & $7.45 \pm 0.25$ & $6.90 \pm 0.10$ & $7.43 \pm 0.37$ & $7.40 \pm 0.87$ & $6.50 \pm 0.52$ \\
\hline & 16 & $7.32 \pm 0.18$ & $6.89 \pm 0.39$ & $7.48 \pm 0.59$ & $7.71 \pm 0.79$ & $6.61 \pm 0.48$ \\
\hline & 23 & $7.48 \pm 0.08$ & $6.81 \pm 0.61$ & $7.20 \pm 0.35$ & $7.14 \pm 0.38$ & $5.73 \pm 1.11$ \\
\hline & $\mathrm{p}$ & $\mathrm{AB}$ & B & $\mathrm{A}$ & A & C \\
\hline \multirow{6}{*}{ Acceptability } & 1 & $7.36 \pm 0.24$ & $7.73 \pm 0.63$ & $8.31 \pm 0.37$ & $8.21 \pm 0.58$ & $6.55 \pm 0.78$ \\
\hline & 5 & $7.87 \pm 0.32$ & $7.58 \pm 0.08$ & $8.72 \pm 0.74$ & $7.68 \pm 0.60$ & $6.08 \pm 0.43$ \\
\hline & 10 & $7.15 \pm 0.15$ & $7.35 \pm 0.15$ & $7.56 \pm 0.51$ & $7.76 \pm 0.55$ & $5.80 \pm 0.45$ \\
\hline & 16 & $7.15 \pm 0.44$ & $7.30 \pm 0.40$ & $7.55 \pm 0.32$ & $7.23 \pm 0.89$ & $5.86 \pm 0.50$ \\
\hline & 23 & $7.22 \pm 0.08$ & $6.99 \pm 0.29$ & $7.16 \pm 0.41$ & $7.00 \pm 0.61$ & $5.19 \pm 1.00$ \\
\hline & $\mathrm{p}$ & B & B & $\mathrm{A}$ & $\mathrm{AB}$ & $\mathrm{C}$ \\
\hline
\end{tabular}

*Values are given as the mean \pm standard deviation $(\mathrm{n}=3)$

**Differences between the means of the samples on the same line are statistically significant at the $\mathrm{p}<0.05$ level

Different groups are indicated by capital letters 
and the dry matter contents remained constant during the storage period. The acetaldehyde and ethanol contents increased in all samples during storage, but the diacetyl contents decreased. The butanone contents did not change much. The starter cultures (thermophilic, probiotic, mesophilic aromatic, and yeast) used for secondary fermentation had a significant influence on the microflora, viscosity, lactic acid, and tyrosine values and the overall acceptability of the products in terms of sensory scores. At the beginning of the storage, sensory scores of all kefir samples were high. Samples A, B, C, and D, which were manufactured using secondary fermentation, were preferred and better accepted than sample E, which was made using the conventional method with kefir grain alone.

In general, the use of secondary fermentation in addition to kefir grains produced better results than the traditional method (produced with kefir grains alone) in terms of microbiological, physicochemical, and sensory properties. Among kefir samples produced by secondary fermentation, the kefir produced by the addition of mesophilic aromatic or yeast cultures to the kefir grains were preferred the most and received the highest scores.

\section{Acknowledgements}

This study was supported by TUBITAK (The Scientific and Technological Research Council of Turkey) under Project number "106 O 314."

\section{Mikrobiološka, fizikalno-kemijska i senzorska svojstva kefira proizvedenog sekundarnom fermentacijom}

\section{Sažetak}

U ovom istraživanju ispitivana su mikrobiološka, fizikalno-kemijska i senzorska svojstva te sastav hlapljivih aromatskih tvari kefira proizvedenog sekundarnom fermentacijom. Uzorci kravljeg mlijeka s 1,5 \% mliječne masti fermentirani su pomoću kefirnih zrnaca do postizanja odgovarajuće $\mathrm{pH}$ vrijednosti $(5,0-5,5)$, nakon čega su inokulirani različitim starter kulturama (termofilna, probotička, mezofilna aromatska i kvasci) u svrhu provođenja sekundarne fermentacije. Tijekom skladištenja u svim je uzorcima kefira došlo do porasta $\mathrm{pH}$ vrijednosti, udjela ugljičnog dioksida, tirozina i količine mliječne kiseline. Međutim, zabilježen je pad broja živih stanica laktokoka, laktobacila, leukonostoka i kvasaca. Također, bez obzira na način proizvodnje (tradicionalno ili sekundarnom fermentacijom) u svim uzrocima je tijekom skladištenja zabilježen porast količine acetaldehida i etanola, dok je količina diacetila opadala. Sadržaj butanona vrlo se malo mijenjao, no pokazao je rastući trend tijekom razdoblja skladištenja. Prilikom provođenja senzorskog ocjenjivanja uzorci kefira proizvedeni sekundarnom fermentacijom okarakterizirani su boljom prihvatljivošću u odnosu na kefir proizveden tradicionalnom metodom. Kefir inokuliran mezofilnom aromatskom kulturom i kulturom kvasaca pokazao se najpoželjnijim prilikom senzorskog ocjenjivanja od strane panela.

\section{Ključne riječi: kefir, sekundarna fermentacija, mikrobiologija, fizikalno-kemijska svojstva, hlapive aromatske tvari, senzorska kvaliteta}

\section{References}

1. Akal, C., Türkmen, N., Koçak, C. (2016): Use of whey in kefir production. Gida 41(5), 351-357. https://doi.org/10.15237/gida.GD16030

2. Anonymous (1976): Food Analysis Methods. The Republic of Turkish Agriculture Forestry and Rural Affairs. General Directorate of Food Business: 65, 796, Turkey.

3. Anonymous (1989): Yoghurt. Turkish Standards Institute 1330, Ankara, Turkey.

4. AOAC (2000): Protein nitrogen content of milk - Kjeldahl method. The Association of Official Analytical Chemists Official Method 991.22.

5. Atlas, R.M. (1997): Handbook of microbiological media. Second edition, CRC Pres. Inc., Edited by Lawrence C. Parks.

6. Ayhan, K., Durlu-Ozkaya, F., Tunail, N. (2005): Commercially important characteristics of Turkish origin domestic strains of Streptococcus thermophilus and Lactobacillus delbrueckii ssp. bulgaricus. International Journal of Dairy Technology 58, 150-157. https://doi.org/10.1111/j.1471-0307.2005.00206.x

7. Beshkova, D., Simova, E., Frengova, G., Simov, Z. (1998): Production of flavour compounds by yoghurt starter cultures. Journal of Industrial Microbiology \& Biotechnology 20, 180-186. https://doi.org/10.1038/sj.jim.2900504 
8. Beshkova, D.M., Simova, E.D., Simov, Z.I., Frengova, G.I., Spasov, Z.N. (2002): Pure cultures for making kefir. Food Microbiology 19, 537-544. https://doi.org/10.1006/fmic.2002.0499

9. Beshkova, D.M., Simova, E.D., Frengova, G.I., Simov, Z.I., Dimitrov, Zh.P. (2003): Production of volatile aroma compounds by kefir starter cultures. International Dairy Journal 13, 529-535. https://doi.org/10.1016/S0958-6946(03)00058-X

10. Bodyfelt, F.W., Tobias, J., Trout, G.M. (1998): The sensory evaluation of dairy products. VanNostrand Reinhold, NewYork, 533 p.

11. Cais-Sokolinska, D., Dankow, R., Pikul, J. (2008): Physicochemical and sensory characteristics of sheep kefir during storage. Acta Scientiarum Polonorum Technologia Alimentaria 7, 63-73.

12. Chaitow, L., Trenev, N. (2002): Online reference included in article [Internet document] URL http://www. natren.com (accessed 01.04.2017.).

13. Collar, C. (1996): Review: Biochemical and technological assessment of the metabolism of pure and mixed cultures of yeast and lactic acid bacteria in breadmaking applications. Food Science and Technology International 2, 349-367. https://doi.org/10.1177/108201329600200601

14. Dinkçi, N., Kesenkaş, H., Korel, F., Kinik, Ö. (2015): An innovative approach: cow/oat milk based kefir. Mljekarstvo 65 (3), 177-186. https://doi.org/10.15567/mljekarstvo.2015.0304

15. Ertekin, B., Guzel-Seydim, Z.B. (2010): Effect of fat replacers on kefir quality. Journal of the Science of Food and Agriculture 90, 543-548. https://doi.org/10.1002/jsfa.3855

16. Garcia-Fontan, M.C.G., Martinez, S., Franco, I, Carballo, J. (2006): Microbiological and chemical changes during the manufacture of kefir made from cows' milk, using a commercial starter culture. International Dairy Journal 16, 762-767. https://doi.org/10.1016/j.idairyj.2005.07.004

17. Güzel-Seydim, Z.B., Seydim, A.C., Greene, A.K., Bodine, A.B. (2000a): Determination of organic acids and volatile flavor substances in kefir during fermentation. Journal of Food Composition and Analysis 13, 35-43. https://doi.org/10.1006/jfca.1999.0842

18. Güzel-Seydim, Z.B., Seydim, A.C., Greene, A.K. (2000b): Organic acids and volatile flavor components evolved during refrigerated storage of kefir. Journal of Dairy Science 83, 275-277. https://doi.org/10.3168/jds.S0022-0302(00)74874-0

19. Güzel-Seydim, Z.B., Wyffels, J.T., Seydim, A.C., Greene, A.K. (2005): Turkish kefir and kefir grains: microbial enumeration and electron microscopic observation. International Journal of Dairy Technology 58, 25-29. https://doi.org/10.1111/j.1471-0307.2005.00177.x

20. Glibowski P., Zielinska, E. (2015): Physicochemical and sensory properties of kefir containing inulin and oligofructose. International Journal of Dairy Technology 68(4), 602-607. https://doi.org/10.1111/1471-0307.12234
21. Hull, M.E. (1947): Studies on milk proteins. II Colorimetric determination of the partial hydrolysis of the protein in milk. Journal of Dairy Science 30, 884. https://doi.org/10.3168/jds.S0022-0302(47)92412-0

22. IDF (1993): Milk: determination of nitrogen content, FIL-IDF (International Dairy Federation) Standard 20B.

23. Irigoyen, A., Akana, I., Castiella, M., Torre, P., Ibanez, F.C. (2005): Microbiological, physicochemical and sensory characteristics of kefir during storage. Food Chemistry 90, 613-620. https://doi.org/10.1016/j.foodchem.2004.04.021

24. Katsiari, M.C., Voutsinas, L.P., Kondyli, E. (2002): Manufacture of yogurt from stored frozen sheep's milk. Food Chemistry 77, 413-420. https://doi.org/10.1016/S0308-8146(01)00367-3

25. Kesenkaş, H., Gürsoy, O., Özbaş, H. (2017): Fermented Foods in Health and Disease Prevention, Eds. J. Frias, C. Martinez-Villaluenga, E. Peñas, Chapter 14: Kefir; pages 339-361, ISBN: 978-0-12-802309-9; Elsevier.

26. Kesenkaş, H., Dinkçi, N., Seçkin, K., Kınık, Ö., Gönç, S. (2011): Antioxidant properties of kefir produced from different cow and soy milk mixtures. Journal of Agricultural Sciences 17, 253-259.

27. Kilic, S., Uysal, H., Akbulut, N., Kavas, G., Kesenkas, H. (1999): Chemical, microbiological and sensory changes in ripening kefirs produced from starters and grains. Ege Üniversitesi Ziraat Fakultesi Dergisi 36, 111-118.

28. Kınık, Ö., Akalın, A.S., Gönç, S. (1998): A research on kefir production and the exchange of organic acids during storage, Milk and Milk Products Symposium, Traditional Milk Products. National Productivity Publications 621, 361-368, Ankara, Turkey.

29. Koroleva, N.S. (1982): Special products (kefir, koumiss, etc.). Proceedings XXI International Dairy Congress, Moscow 2, 146-151.

30. Magra, T.I., Antoniou, K.D., Psomas, E.I. (2012): Effect of milk fat, kefir grain inoculums and storage time on the flow properties and microbiological characteristics of kefir. Journal of Texture Studies 43, 299-308. https://doi.org/10.1111/j.1745-4603.2011.00343.x

31. Montanuci, F.D., Pimentel, T.C., Garcia, S., Prudencio, S.H. (2012): Effect of starter culture and inulin addition on microbial viability, texture, and chemical characteristics of whole or skim milk kefir. Ciênc. Tecnol. Aliment. Campinas 32 (4), 850-861. https://doi.org/10.1590/S0101-20612012005000119

32. Marshall, V.M. (1984): Flavour development in fermented milks. The Microbiology and Biochemistry of Cheese and Fermented Milk. Eds. Davies, F.L., Law, B.M. Elsevier Applied Science. Pp. 153-186. London.

33. Muir, D.D., Tamime, A.Y., Wszolek, M. (1999): Comparison of the sensory profiles of kefir, buttermilk and yogurt. International Journal of Dairy Technology 52, 129-134. https://doi.org/10.1111/j.1471-0307.1999.tb02854.x 
34. Otles, S., Cagindi, Ö. (2003): Kefir: A probiotic dairy-composition, nutritional and therapeutic aspects. Pakistan Journal of Nutrition 2, 54-59. https://doi.org/10.3923/pjn.2003.54.59

35. Ott, A., Germond, J.E., Baumgartner, M., Chaintreau, A. (1999): Aroma comparisons of traditional and mild yogurts: Headspace gas chromatography quantification of volatiles and origin of alfa diketons. Journal of Agriculture and Food Chemistry 47, 2379-2385. 161

36. Ott, A., Hugi, A., Baumgartner, M., Chaintreau, A. (2000): Sensory investigation of yogurt flavor perception: Mutual influence of volatiles and acid. Journal of Agriculture and Food Chemistry 48, 441-450. https://doi.org/10.1021/jf990432x

37. Özer, B., Atasoy, F, Özer, D. (2000): A Study on production of kefir with starter culture and two-stage fermentation. Milk Microbiology and Additives. VI. Milk and Milk Products Symposium (edited by M. Demirci). Pp. 354-362, Tekirdağ, Turkey.

38. Pawlos, M., Znamirowska, A., Szajnar, K., Kalicka, D. (2016): The influence of the dose of calcium bisglycinate on physicochemical properties, sensory analysis and texture profile of kefirs during 21 days of cold storage. Acta Scientiarum Polonorum Technologia Alimentaria 15(1), 37-45. https://doi.org/10.17306/J.AFS.2016.1.4

39. Puhan, Z. (1988): Resultats of questionnaire 1785B Fermented Milks. Bulletin of IDF,227. 138-164.

40. Rasic, J.L., Kurmann, J.A. (1978): Yoghurt: Scientific Grounds, Technology, Manufacture and Preparations. (published by Authors). Pp. 427. Copenhagen, Denmark.
41. Sady, M., Domagala, J., Najgebauer-Lejko, D., Grega, T. (2009): Effect of whey protein concentrate addition on texture and rheological properties of kefir produced from skimmed milk. Biotechnology in Animal Husbandry 25 (5-6), 763-771.

42. Sarkar, S. (2007): Potential of kefir as a dietetic beverage - a review. British Food Journal, 109, 280-290. https://doi.org/10.1108/00070700710736534

43. Sarkar, S. (2008): Biotechnological innovations in kefir production- a review. British Food Journal, 110, 283-295. https://doi.org/10.1108/00070700810858691

44. Steinsholt, K., Calbert, H.E. (1960). A rapid colorimetric method for determination of lactic acid in milk and milk products. Milchwissenscahft 15, 7-10.

45. Ulbert, F. 1991. Headspace gas chomatos rafhic estimation of some yoghurt volatiles. Journal - Association of Official Analytical Chemists 74, 630-634.

46. Vieira, C.P., Alvares, T.S., Gomes, L.S., Torres, A.G., Paschoalin, V.M.F., Conte-Junior, C.A. (2015): Kefir grains change fatty acid profile of milk during fermentation and storage. Plos One 10 (10), 1-18. https://doi.org/10.1371/journal.pone.0139910

47. Wszolek, M., Tamime, A.Y., Muir, D.D., Barclay, M.N.I. (2001): Properties of kefir made in Scotland and Poland using bovine, caprine and ovine milk with different starter cultures. Lebensmittel-Wissenschaft \& Technologie, 34, 251-261. https://doi.org/10.1006/fstl.2001.0773 